\title{
UPAYA MENINGKATKAN KOMPETENSI GURU DALAM MENYUSUN RENCANA PROGRAM PEMBELAJARAN HARIAN MELALUI BIMBINGAN BERKELANJUTAN
}

\author{
Ni Nyoman Srinadi \\ TK Negeri Pembina Kecamatan Banjar \\ e-mail: Srinadi@gmail.com
}

\begin{abstract}
Abstrak
Pembangunan bangsa dan negara dewasa ini diarahkan pada peningkatan kualitas sumber daya manusia. Peningkatan kualitas itu melalui pendidikan sebagai instrumen untuk mengembangkan potensi dan kompetensi dalam rangka pengembangan sumber daya manusia tersebut. Kompetensi guru dalam melaksanakan proses belajar mengajar tidak hanya ditentukan oleh kompetensi mereka tetapi juga kompetensi semua yang terkait dalam mengatur semua sumber daya yang tersedia. Penelitian ini berfokus pada kompetensi guru dalam proses belajar mengajar yang menekankan pada prestasi guru dalam melangsungkan kegiatan tersebut. Peran serta dan upaya kepala sekolah dalam mengoptimalkan kompetensi gurupun sangat berpengaruh. Dewasa ini, kinerja guru menunjukkan bahwa dalam melakukan proses belajar mengajar diawali dengan membuat rencana pembelajaran dan diakhiri dengan mengimplementasikannya ke para siswa-siswa, dan juga prestasi guru dalam melakukan proses belajar mengajar adalah bagaimana cara guru tersebut dalam menciptakan situasi belajar mengajar yang menyenangkan dan lingkungan sekolah yang kondusif. Guru belum optimal dalam tugasnya baik dalam mengembangkan kemampuannya, ssosial maupun kepribadiannya.
\end{abstract}

Kata kunci: kompetensi guru, sumber daya, berkualitas

\begin{abstract}
The development of the nation and state today is directed at improving quality human Resources. Quality improvement through education as instruments to develop potential and competence in order human resource development. Teacher competency in carrying out learning processes is not only determined by competence but also the competencies of all those involved in managing all sources available power. This study focuses on teacher competence in the process teaching and learning which emphasizes the teacher's performance in carrying out the activity. The role and effort of the principal in optimizing teacher competence is very influential. Today, teacher performance shows that in conducting the teaching and learning process begins with making learning plan and ends with implementing it to the participants students, and also the teacher's performance in the teaching and learning process is how the teacher creates a teaching and learning situation fun and conducive school environment. The teacher is not optimal in their duties both in developing their abilities, ssosial and his personality.
\end{abstract}

Keywords: teacher competence, resources, quality 


\section{Pendahuluan}

Dalam meraih mutu pendidikan yang baik sangat dipengaruhi oleh kinerja guru dalam melaksanakan tugasnya sehingga kinerja guru menjadi tuntutan penting untuk mencapai keberhasilan pendidikan. Secara umum mutu pendidikan yang baik menjadi tolok ukur bagi keberhasilan kinerja yang ditunjukkan guru. Namun, kenyataan menunjukkan bahwa kualitas guru di Indonesia masih tergolong relatif rendah. Hal ini antara lain disebabkan oleh tidak terpenuhinya kualitas pendidikan. Maka dari itu, kinerja guru sangat diperhatikan, dan berusaha untuk terus ditingkatkan (Markos \& Sridevi, 2010).

Mataheru (1988) menekankan bahwa salah satu faktor yang perlu diperhatikan dalam meningkatkan mutu pendidikan adalah kinerja guru. Kinerja guru merupakan salah satu faktor yang menentukan keberhasilan sekolah. Hal ini dikarenakan keefektifan sekolah lebih banyak ditentukan oleh kinerja guru. Kinerja merupakan unsur perilaku yang ditampilkan oleh seseorang sehubungan dengan pekerjaannya (Harris, dkk., 1979; Steers \& Porter, 1983). Selanjutnya, Depdikbud (1994) menyatakan bahwa kinerja sebagai kombinasi atau paduan antara motivasi yang ada pada diri seseorang dan kemampuannya melaksanakan suatu pekerjaan. Dari uraian tersebut, kinerja guru dapat diartikan sebagai perilaku seorang guru dalam melaksanakan proses pembelajaran di kelas. Keberhasilan guru melaksanakan proses pembelajaran tidak hanya ditentukan oleh kemampuan guru saja, tetapi peran kepala sekolah dalam membantu terwujudnya kegiatan pembelajaran yang efektif juga sangat diperlukan.

Salah satu upaya dalam pengembangan profesi guru dengan cara peningkatan dan pengembangan keterampilan dapat diperoleh melalui proses pembelajaran. Pengembangan profesional guru dipelajari dan disajikan dalam sastra relevan di banyak berbeda cara. Tapi selalu merupakan inti dari upaya tersebut adalah memahami bahwa pengembangan profesional adalah tentang guru belajar, belajar cara belajar, dan mengubah pengetahuan mereka praktek untuk kepentingan siswa mereka (Avalos, 2011). Pada prinsipnya, dapat dikatakan bahwa tujuan utama dari pendidikan, secara umum, pencapaian persiapan optimal profesional masa depan.

Kepala sekolah merupakan penentu arah kebijakan sekolah, yang akan menentukan bagaimana tujuan-tujuan sekolah dan pendidikan pada umumnya direalisasikan. Danim (2002) mengatakan bahwa kepala sekolah merupakan factor kunci dari efektif tidaknya suatu sekolah karena kepala sekolah memainkan peranan yang sangat penting pada keseluruhan spektrum pengelolaan sekolah. Kepala sekolah merupakan kunci utama penyelenggaraan pendidikan di sekolah. Oleh karena itu, kinerja guru yang merupakan salah satu faktor penentu keberhasilan sekolah diperlukan suatu manajemen kinerja guru yang tepat oleh kepala sekolah. Menurut Ruky (2006), manajemen kinerja merupakan usaha, kegiatan, atau program optimalisasi kinerja guru yang diprakarsai dan dilaksanakan oleh kepala sekolah.

Manajemen kinerja guru menunjuk bagaimana upaya kepala sekolah mengoptimalkan kinerja guru tersebut, sehingga kinerja mempunyai makna lebih luas bukan hanya sebagai hasil kerja, tetapi juga bagaimana proses kerja berlangsung. Sergiovanni, Beerlingame, Coombs dan Thurston (1987) (dalam Danim, 2002) mengungkapkan bahwa kepala sekolah merupakan orang yang memiliki tanggung jawab utama terhadap guru dan staf dapat bekerja sesuai dengan tugas pokok dan fungsinya. Lebih lanjut Mantja (2005) mengungkapkan bahwa kepala sekolah dapat melakukan pembinaan terhadap para guru untuk meningkatkan kemampuannnya dalam melaksanakan tugastugasnya.

Secara lebih luas Stoops \& Johnson (1967) mengungkapkan bahwa kepala sekolah sebagai pemimpin pengajaran harus mengadakan pembinaan bagi guru-guru secara kontinyu sehingga mereka melaksanakan tugas dengan baik agar mampu membimbing para siswanya. Kepemimpinan kepala sekolah yang efektif adalah kepemimpinan yang mampu memberdayakan para guru untuk melaksanakan proses pembelajaran dengan baik, lancar, dan produktif (Mulyasa, 2005). Berdasarkan uraian tersebut maka dapat diperoleh gambaran tentang optimalisasi kinerja guru dalam melaksanakan proses pembelajaran, yaitu sebagai 
upaya yang dilakukan kepala sekolah mengoptimalkan kinerja guru dalam melaksanakan proses pembelajaran.

Salah satu aspek yang menarik untuk dikaji dari sosok seorang guru adalah aspek kinerja, karena kinerja guru menurut merupakan input yang paling penting dalam penyelenggaraan pendidikan (Nadeem \& et.al, 2011). Akan tetapi berdasarkan Fakta menunjukkan kinerja guru masih belum optimal. Belumoptimalnya kinerja guru, hal tersebut ditunjukkan antara lain guru tidak membuatRencana Pelaksanaan Pembelajaran (RPP), mengabaikan kelengkapan administrasi guru, memberikan tugas tanpa adanya proses tatap muka, kurangnya bahan ajar yang menarik penggunaan model dan metode yang monoton, dan evaluasi pembelajaran yang belum optimal.

Perencanaan pembelajaran merupakan langkah yang sangat penting sebelum pelaksanaan pembelajaran. Perencanaan yang matang diperlukan supaya pelaksanaan pembelajaran berjalan secara efektif. Perencanaan pembelajaran dituangkan ke dalam Rencana Kegiatan Mingguan(RKM) dan Rencana Kegiatan Harian (RKH) atau beberapa istilah lain seperti desain pembelajaran, skenario pembelajaran dan lain sebagainya. RKM dan RKH memuat tingkat pencapaian perkembangan, indikator yang akan dicapai, materi yang akan dipelajari, metode pembelajaran, langkah pembelajaran, media pembelajaran, dan sumber belajar serta penilaian.

Kualitas pendidikan sangat ditentukan oleh kemampuan sekolah dalam mengelola proses pembelajaran, dan lebih khusus lagi adalah proses pembelajaran yang terjadi di kelas, mempunyai andil dalam menentukan kualitas pendidikan konsekuensinya, adalah guru harus mempersiapkan (merencanakan ) segala sesuatu agar proses pembelajaran di kelas berjalan dengan efektif".

Guru harus mampu berperan sebagai desainer (perencana), implementor (pelaksana), dan evaluator (penilai) kegiatan pembelajaran. Guru merupakan faktor yang paling dominan karena di tangan gurulah keberhasilan pembelajaran dapat dicapai. Kualitas mengajar guru secara langsung maupun tidak langsung dapat mempengaruhi kualitas pembelajaran pada umumnya. Seorang guru dikatakan profesional apabila (1) serius melaksanakan tugas profesinya, (2) bangga dengan tugas profesinya, (3) selalu menjaga dan berupaya meningkatkan kompetensinya, (4) bekerja dengan sungguh tanpa harus diawasi, (5) menjaga nama baik profesinya, (6) bersyukur atas imbalan yang diperoleh dari profesinya.

Peraturan Pemerintah Nomor 19 Tahun 2005 tentang 8 Standar Nasional Pendidikan menyatakan standar proses merupakan salah satu SNP untuk satuan pendidikan dasar dan menengah yang mencakup: 1) Perencanaan proses pembelajaran, 2) Pelaksanaan proses pembelajaran, 3) Penilaian hasil pembelajaran, 4) dan pengawasan proses pembelajaran.

Silabus dan RKH dikembangkan oleh guru pada satuan pendidikan. Guru pada satuan pendidikan berkewajiban menyusun silabus, RKM dan RKH secara lengkap dan sistematis agar pembelajaran berlangsung secara interaktif, inspiratif, menyenangkan, menantang, memotivasi peserta didik untuk berpartisipasi aktif, serta memberikan ruang yang cukup bagi prakarsa, kreativitas, dan kemandirian sesuai dengan bakat, minat dan perkembangan fisik serta psikologis peserta didik.

Masalah yang terjadi di lapangan masih ditemukan adanya guru (baik di sekolah negeri maupun swasta) yang tidak bisa memperlihatkan RKM dan RKH yang dibuat dengan alasan ketinggalan di rumah dan bagi guru yang sudah membuat RKM dan RKH masih ditemukan adanya guru yang belum melengkapi komponen tujuan pembelajaran dan penilaian, serta langkah-langkah kegiatan pembelajarannya masih dangkal. Pada komponen penilaian ( penskora) sebagian besar guru tidak lengkap membuatnya dengan alasan sudah tahu dan ada di kepala. Sedangkan pada komponen tujuan pembelajaran, materi ajar, metode pembelajaran, dan sumber belajar sebagian besar guru sudah membuatnya. Masalah yang lain yaitu sebagian besar guru belum mendapatkan pelatihan pengembangan RKH. Selama ini guru-guru yang mengajar di sekolah sedikit/jarang mendapatkan kesempatan untuk mengikuti berbagai Diklat Peningkatan Profesionalisme. Hal ini menyebabkan banyak guru yang belum tahu dan memahami penyusunan/pembuatan RKH secara baik/lengkap. Beberapa guru mengadopsi RKH orang lain. Hal ini peneliti ketahui pada saat mengadakan 
supervisi akademik (supervisi kunjungan kelas) ke sekolah binaan. Permasalahan tersebut berpengaruh besar terhadap pelaksanaan proses pembelajaran.

Dengan keadaan demikian, peneliti sebagai kepala sekolah berusaha untuk memberi bimbingan berkelanjutan pada guru di sekolah kami dalam menyusun RKM dan RKH secara lengkap sesuai dengan tuntutan pada standar proses dan standar penilaian yang merupakan bagian dari standar nasional pendidikan. Hal itu juga sesuai.

Rencana Pelaksanaan Pembelajaran harus dibuat agar kegiatan pembelajaran berjalan sistematis dan mencapai tujuan pembelajaran. Tanpa Rencana Program Pembelajaran, biasanya pembelajaran menjadi tidak terarah. Oleh karena itu, guru harus mampu menyusun RKM dan RKH dengan lengkap berdasarkan silabus yang disusunnya. Rencana Program Pembelajaran sangat penting bagi seorang guru karena merupakan acuan dalam melaksanakan proses pembelajaran.

Sukarni (2014), bimbingan berkelanjutan dapat meningkatkan motivasi guru dalam menyusun RPP dengan lengkap. Guru menunjukkan keseriusan dalam memahami dan menyusun RPP apalagi setelah mendapatkan bimbingan pengembangan/penyusunan RPP dari peneliti. Informasi ini peneliti peroleh dari hasil pengamatan pada saat mengadakan wawancara dan bimbingan pengembangan/penyusunan RPP kepada para guru

Sutomo (2017) menyatakan bahwa Bimbingan berkelanjutan dapat meningkatkan motivasi guru dalam menyusun RPP dengan lengkap. Guru menunjukkan keseriusan dalam memahami dan Upaya Meningkatkan Kompetensi Guru dalam Menyusun Rencana Pelaksanaan Pembelajaran menyusun RPP apalagi setelah mendapatkan bimbingan pengembangan/penyusunan RPP dari peneliti. Informasi ini peneliti peroleh dari hasil pengamatan pada saat mengadakan wawancara dan bimbingan pengembangan/penyusunan RPP kepada para guru.

Kuka (2017) menyatakan hal yang sama dimana Pemberian bimbingan berkelanjutan dapat meningkatkan motivasi dan kinerja guru dalam menyusun RPP dengan baik dan lengkap. Guru menunjukkan keaktifan dalam memahami dan menyusun RPP setelah mendapatkan bimbingan RPP dari peneliti

Berdasarkan latar belakang, identifikasi, dan pembatasan masalah di atas, diajukan rumusan masalah sebagai berikut. Apakah dengan bimbingan berkelanjutan akan dapat meningkatkan kompetensi guru dalam menyusun RKM dan RKH di TK Negeri Pembina Kecamatan Banjar?

Penelitian Tindakan Sekolah (PTS) ini bertujuan untuk meningkatkan kompetensi guru dalam menyusun Rencana Pelaksanaan Pembelajaran melalui bimbingan berkelanjutan di sekolah tempat peneliti bekerja.

\section{Metode}

Setting dalam penelitian ini meliputi: tempat penelitian, waktu penelitian, jadwal penelitian, dan siklus penelitian. Penelitian Tindakan Sekolah dilaksanakan di TK Negeri Pembina Kecamatan Banjar. Pemilihan sekolah tersebut bertujuan untuk meningkatkan kompetensi guru dalam menyusun rencana perlaksanaan pembelajaran $(\mathrm{RKH})$ dengan lengkap. PTS ini dilaksanakan pada semester dua / genap tahun pelajaran 2018-2019 selama kurang lebih satu setengah bulan mulai Januari sampai dengan Maret 2019. Jadwal pelaksanaan penelitian seperti pada Tabel berikut.

Tabel 1. Jadwa; Pelaksanaan Penelitian

\begin{tabular}{ccc}
\hline no. & Kegiatan & Waktu \\
\hline 1 & Membuat proposal & 24 s.d. 25 Januari 2019 \\
2 & Merevisi proposal & 28 s.d. 29 Januari 2019 \\
3 & Melaksanakan PTS & 1 Februari s.d. 28 Februari 2019 \\
4 & Membuat laporan PTS & 4 s.d. 8 Maret 2019 \\
5 & Mempresentasikan hasil PTS & 11 s.d. 13 Maret 2019 \\
\hline
\end{tabular}


Penelitian Tindakan Sekolah dilaksanakan melalui dua siklus untuk melihat peningkatan kompetensi guru dalam menyusun Rencana Pelaksanaan Pembelajaran (RKH\&RKM ).

Sebelum PTS dilaksanakan, dibuat berbagai input instrument yang digunakan untuk mendapatkan data dan informasi. Yang menjadi subyek dalam PTS ini adalah guru TK Negeri Pembina Kecamatan Banjar. Sumber data dalam PTS ini adalah rencana pelaksanaan pembelajaran yang sudah dibuat guru. Teknik pengumpulan data dalam penelitian ini adalah wawancara, observasi, dan diskusi. Wawancara dipergunakan untuk mendapatkan data atau informasi tentang pemahaman guru terhadap $\mathrm{RKH}$. Observasi dipergunakan untuk mengumpulkan data dan mengetahui kompetensi guru dalam menyusun Rencana Pelaksanaan Pembelajaran dengan lengkap dan diskusi dilakukan antara peneliti dengan guru.

Alat pengumpulan data dalam PTS ini antara lain wawancara, observasi, dan diskusi. Wawancara menggunakan panduan wawancara untuk mengetahui kemampuan awal yang dimiliki guru tentang Rencana Pelaksanaan Pembelajaran. Observasi menggunakan lembar observasi untuk mengetahui komponen $\mathrm{RKH}$ yang telah dibuat dan yang belum dibuat oleh guru. Diskusi dilakukan dengan maksud untuk sharing pendapat antara peneliti dengan guru.

Penelitian ini berbentuk Penelitian Tindakan Sekolah (School Action Research), yaitu sebuah penelitian yang merupakan kerjasama antara peneliti dan guru, dalam meningkatkan kemampuan guru agar menjadi lebih baik dalam menyusun rencana pelaksanaan pembelajaran. Metode yang digunakan dalam penelitian ini adalah metode deskriptif, dengan menggunakan teknik persentase untuk melihat peningkatan yang terjadi dari siklus ke siklus. "Metode deskriptif dapat diartikan sebagai prosedur pemecahan masalah yang diselidiki dengan menggambarkan/melukiskan keadaan subjek/objek penelitian (seseorang, lembaga, masyarakat, dan lain-lain) pada saat sekarang berdasarkan fakta-fakta yang tampak atau sebagaimana adanya (Nawawi, 1985:63). Dengan metode ini peneliti berupaya menjelaskan data yang peneliti kumpulkan melalui komunikasi langsung atau wawancara, observasi/pengamatan, dan diskusi yang berupa persentase atau angka-angka.

Penelitian ini bertujuan untuk mendeskripsikan kesulitan-kesulitan yang dialami oleh guru dalam menyusun $\mathrm{RKH}$. Selanjutnya peneliti memberikan alternatif atau usaha guna meningkatkan kemampuan guru dalam membuat rencana pelaksanaan pembelajaran.

Hal-hal penting yang harus diperhatikan dalam Penelitian Tindakan Sekolah, menurut Sudarsono, F.X, (1999:2) yakni:

a) Rencana

Tindakan apa yang akan dilakukan untuk meningkatkan kompetensi guru dalam menyusun $\mathrm{RKH}$ secara lengkap. Solusinya yaitu dengan melakukan : a) wawancara dengan guru dengan menyiapkan lembar wawancara, b) Diskusi dalam suasana yang menyenangkan dan c) memberikan bimbingan dalam menyusun RKH secara lengkap. b) Pelaksanaan:

Apa yang dilakukan oleh peneliti sebagai upaya meningkatkan kompetensi guru dalam menyusun $\mathrm{RKH}$ yang lengkap yaitu dengan memberikan bimbingan berkelanjutan pada guru sekolah binaan .

c) Observasi:

Peneliti melakukan pengamatan terhadap $\mathrm{RKH}$ yang telah dibuat untuk memotret seberapa jauh kemampuan guru dalam menyusun RKH dengan lengkap, hasil atau dampak dari tindakan yang telah dilaksanakan oleh guru dalam mencapai sasaran.Selain itu juga peneliti mencatat hal-hal yang terjadi dalam pertemuan dan wawancara. Rekaman dari pertemuan dan wawancara akan digunakan untuk analisis dan komentar kemudian. d) Refleksi:

Peneliti mengkaji, melihat, dan mempertimbangkan hasil atau dampak dari tindakan yang telah dilakukan. Berdasarkan hasil dari refleksi ini, peneliti bersama guru melaksanakan revisi atau perbaikan terhadap $\mathrm{RKH}$ yang telah disusun agar sesuai dengan rencana awal yang mungkin saja masih bisa sesuai dengan yang peneliti inginkan. 
Prosedur penelitian adalah suatu rangkaian tahap-tahap penelitian dari awal sampai akhir. Penelitian ini merupakan proses pengkajian sistem berdaur sebagaimana kerangka berpikir yang dikembangkan oleh Suharsimi Arikunto dkk. Prosedur ini mencakup tahaptahap: (1) perencanaan, (2) pelaksanaan, (3) pengamatan, dan (4) refleksi. Keempat kegiatan tersebut saling terkait dan secara urut membentuk sebuah siklus. Penelitian Tindakan Sekolah merupakan penelitian yang bersiklus, artinya penelitian dilakukan secara berulang dan berkelanjutan sampai tujuan penelitian dapat tercapai."

Alur PTS dapat dilihat pada Gambar berikut :

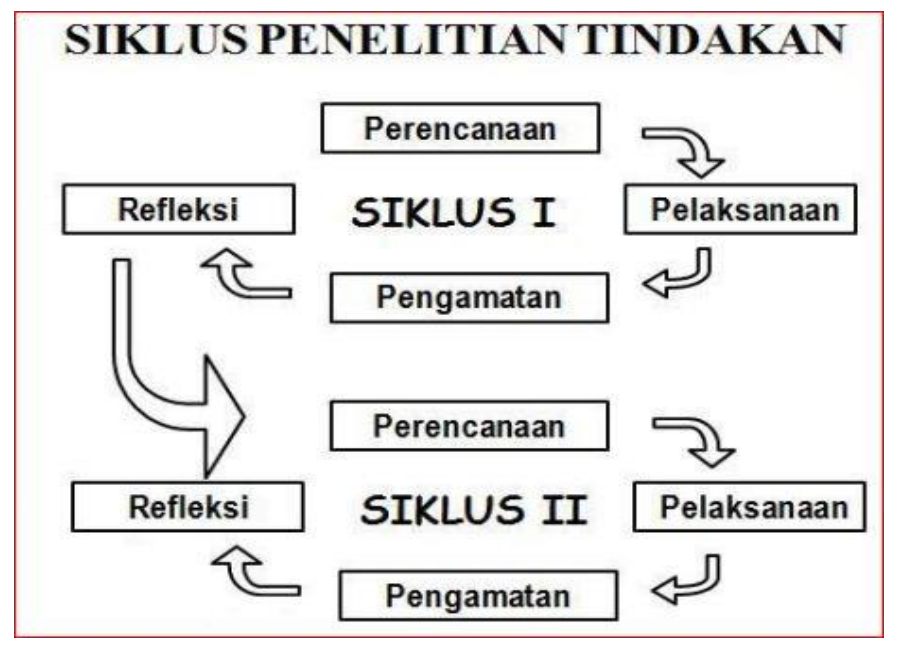

Gambar 1. Siklus Penelitian Tindakan

Pelaksanaan dilakukan dalam dua siklus yaitu:

Siklus Pertama (Siklus I)

a) Peneliti merencanakan tindakan pada siklus I (membuat format/instrumen wawancara, penilaian $\mathrm{RKH}$, rekapitulasi hasil penyusunan $\mathrm{RKH}$ ).

b) Peneliti memberi kesempatan kepada guru untuk mengemukakan kesulitan atau hambatan dalam menyusun Rencana Pelaksanaan Pembelajaran.

c) Peneliti menjelaskan kepada guru tentang pentingnya RKH dibuat secara lengkap.

d) Peneliti memberikan bimbingan dalam pengembangan $\mathrm{RKH}$.

e) Peneliti melakukan observasi/pengamatan terhadap $\mathrm{RKH}$ yang telah dibuat guru.

f) Peneliti melakukan revisi atau perbaikan penyusunan rencana pelaksanaan pembelajaran yang lengkap.

g) Peneliti dan guru melakukan refleksi.

Siklus Kedua (Siklus II)

a) Peneiti merencanakan tindakan pada siklus II yang mendasarkan pada revisi/perbaikan pada siklus I, seperti menugasi guru menyusun RKH yang kedua, mengumpulkan, dan melakukan pembimbingan penyusunan $\mathrm{RKH}$.

b) Peneliti melaksanakan tindakan sesuai dengan rencana pada siklus II.

c) Peneliti melakukan observasi/pengamatan terhadap $\mathrm{RKH}$ yang telah dibuat guru.

d) Peneliti melakukan perbaikan atau revisi penyusunan $\mathrm{RKH}$.

e) Peneliti dan guru melakukan refleksi.

Peneliti mengharapkan secara rinci indikator pencapaian hasil paling rendah $78 \%$ guru membuat kesebelas komponen Rencana Pelaksanaan Pembelajaran diantaranya : (1) Komponen identitas mata pelajaran diharapkan ketercapaiannya 100\%. (2) Komponen standar kompetensi diharapkan ketercapaiannya 85\%. (3)Komponen kompetensi dasar diharapkan ketercapaiannya $85 \%$. (4) Komponen indikator pencapaian kompetensi 
diharapkan ketercapaiannya 75\%. (5) Komponen tujuan pembelajaran diharapkan ketercapaiannya 75\%. (6) Komponen materi pembelajaran diharapkan kecercapaian 75\%. (7) Komponen alokasi waktu diharapkan ketercapaiannya 75\%. (8) Komponen metode pembelajaran diharapkan kecercapaiannya 75\%.(9) Komponen langkah-langkah kegiatan pembelajaran diharapkan ketercapaiannya 70\%. (10) Komponen sumber belajar diharapkan ketercapaiannya 70\%.(11) Komponen penilaian diharapkan ketercapaiannya $75 \%$.

\section{Hasil dan Pembahasan}

Dari hasil wawancara peneliti memperoleh informasi bahwa semua guru belum tahu kerangka penyusunan $\mathrm{RKH}$, hanya sekolah yang memiliki dokumen standar proses (satu buah), dua orang guru yang pernah mengikuti pelatihan pengembangan $\mathrm{RKH}$ tetap belum bisa maksimal, umumnya guru mengadopsi dan mengadaptasi $\mathrm{RKH}$, kebanyakan guru tidak tahu dan tidak paham menyusun $\mathrm{RKH}$ secara lengkap, mereka setuju bahwa guru harus menggunakan $\mathrm{RKH}$ dalam melaksanakan proses pembelajaran yang dapat dijadikan acuan/pedoman dalam proses pembelajaran. Selain itu, kebanyakan guru belum tahu dengan komponen-komponen RKH secara lengkap.

Berdasarkan hasil observasi peneliti terhadap RKH yang dibuat guru (khusus pada siklus I), diperoleh informasi/data bahwa masih ada guru yang tidak melengkapi RKH-nya dengan komponen dan sub-subkomponen RKH tertentu, misalnya komponen indikator dan penilaian hasil belajar (pedoman penskoran). Rumusan kegiatan siswa pada komponen langkahlangkah kegiatan pembelajaran masih kurang tajam, interaktif, inspiratif, menantang, dan sistematis.

Dilihat dari segi kompetensi guru, terjadi peningkatan dalam menyusun Rencana Pelaksanaan Pembelajaran dari siklus ke siklus. Hal itu dapat dilihat pada lampiran Rekapitulasi Hasil Penyusunan RKH dari Siklus ke Siklus.

\section{Siklus I (Pertama)}

Siklus pertama terdiri dari empat tahap yakni: (1) perencanaan, (2) pelaksanaan, (3) observasi, dan (4) refleksi. Perencanaan ( Planning ) dilakukan hal2 sebagai berikut: (a). Membuat lembar wawancara, (b). Membuat format/instrumen penilaian RKH, (c). Membuat format rekapitulasi hasil penyusunan RKH siklus I dan II dan (d). Membuat format rekapitulasi hasil penyusunan $\mathrm{RKH}$ dari siklus ke siklus

Yang kedua adalah Pelaksanaan (Acting). Pada saat awal siklus pertama indikator pencapaian hasil dari setiap komponen $\mathrm{RKH}$ belum sesuai/tercapai seperti rencana/keinginan peneliti. Hal itu dibuktikan dengan masih adanya komponen $\mathrm{RKH}$ yang belum dibuat oleh guru. Sebelas komponen RKH yakni: 1) identitas mata pelajaran, 2) standar kompetensi, 3) kompetensi dasar, 4) indikator pencapaian kompetensi, 5) tujuan pembelajaran, 6) materi ajar, 7) alokasi waktu, 8) metode pembelajaran, 9) langkah-langkah kegiatan pembelajaran, 10) sumber belajar, 11) penilaiaan hasil belajar ( soal, pedoman penskoran, dan kunci jawaban). Hasil observasi pada siklus kesatu dapat dideskripsikan berikut ini:

Observasi dilaksanakan Selasa, 1 Februari 2019, terhadap semua guru. Semuanya menyusun $\mathrm{RKH}$, tapi masih ada guru yang belum melengkapi RKH-nya baik dengan komponen maupun sub-sub komponen RKH tertentu. Satu orang tidak melengkapi RKH-nya dengan komponen indikator pencapaian kompetensi. Untuk komponen penilaian hasil belajar, dapat dikemukakan sebagai berikut: 1) Satu orang tidak melengkapinya dengan teknik dan bentuk instrumen, 2) Satu orang tidak melengkapinya dengan teknik, bentuk instumen, soal, pedoman penskoran, dan kunci jawaban, 3) Dua orang tidak melengkapinya dengan teknik, pedoman penskoran, dan kunci jawaban, 4) Satu orang tidak melengkapinya dengan soal, pedoman penskoran, dan kunci jawaban, 5) Satu orang tidak melengkapinya dengan pedoman penskoran dan kunci jawaban. Selanjutnya mereka dibimbing dan disarankan untuk melengkapinya. 
Siklus II (Kedua)

Siklus kedua juga terdiri dari empat tahap yakni: (1) perencanaan, (2) pelaksanaan, (3) observasi, dan (4) refleksi. Hasil observasi pada siklus kedua dapat dideskripsikan berikut ini:

Observasi dilaksanakan Selasa, 23 September 2014, terhadap semua guru. Semuanya menyusun $\mathrm{RKH}$, tapi masih ada guru yang keliru dalam menentukan kegiatan siswa dalam langkah-langkah kegiatan pembelajaran dan metode pembelajaran, serta tidak memilah/ menguraikan materi pembelajaran dalam sub-sub materi. Untuk komponen penilaian hasil belajar, dapat dikemukakan sebagai berikut: 1) Satu orang keliru dalam menentukan teknik dan bentuk instrumennya, 2) Satu orang keliru dalam menentukan bentuk instrumen berdasarkan teknik penilaian yang dipilih, 3) Dua orang kurang jelas dalam menentukan pedoman penskoran, 4) Satu orang tidak menuliskan rumus perolehan nilai siswa. Selanjutnya mereka dibimbing dan disarankan untuk melengkapinya.

Penelitian Tindakan Sekolah dilaksanakan di TK Negeri Pembina Kecamatan Banjar yang merupakan sekolah tempat peneliti bertugas sebagai kepala sekolah berstatus swasta, terdiri atas dua orang guru, dan dilaksanakan dalam dua siklus. kedua guru tersebut menunjukkan sikap yang baik dan termotivasi dalam menyusun RKH dengan lengkap. Hal ini peneliti ketahui dari hasil pengamatan pada saat melakukan wawancara dan bimbingan penyusunan $\mathrm{RKH}$. Selanjutnya dilihat dari kompetensi guru dalam menyusun $\mathrm{RKH}$, terjadi peningkatan dari siklus ke siklus.

Komponen Identitas Mata Pelajaran. Pada siklus pertama semua guru (dua orang) mencantumkan identitas mata pelajaran dalam $\mathrm{RKH}$-nya (melengkapi $\mathrm{RKH}$-nya dengan identitas mata pelajaran). Jika dipersentasekan, 100\% (sangat baik). Pada siklus kedua kedua guru tersebut mencantumkan identitas mata pelajaran dalam RKH-nya. Semuanya mendapat skor 4 (sangat baik). Jika dipersentasekan, 100\%

Komponen Standar Kompetensi. Pada siklus pertama semua guru mencantumkan standar kompetensi dalam RKH-nya (melengkapi RKH-nya dengan standar kompetensi). Jika dipersentasekan, 100\%. Masing-masing guru mendapat skor yang baik..

Komponen Kompetensi Dasar. Pada siklus pertama semua guru (dua orang) mencantumkan kompetensi dasar dalam RKH-nya (melengkapi RKH-nya dengan kompetensi dasar). Jika dipersentasekan, $75 \%$. Satu orang guru masing-masing mendapat skor 1, 2, dan 3 (kurang baik, cukup baik, dan baik). Satu orang guru yang lain mendapat skor 4 (sangat baik). Pada siklus kedua kedelapan guru tersebut mencantumkan kompetensi dasar dalam RKH-nya. dua orang mendapat skor 4 (sangat baik). Jika dipersentasekan, $100 \%$, terjadi peningkatan $25 \%$ dari siklus I.

Komponen Indikator Pencapaian Kompetensi. Pada siklus pertama saru orang guru mencantumkan indikator pencapaian kompetensi dalam RKH-nya (melengkapi RKH-nya dengan indikator pencapaian kompetensi). Sedangkan satu orang tidak mencantumkan/melengkapinya dari siklus I.

Komponen Tujuan Pembelajaran. Pada siklus pertama semua guru (delapan orang) mencantumkan tujuan pembelajaran dalam RKH-nya (melengkapi RKH-nya dengan tujuan pembelajaran). Jika dipersentasekan, $75 \%$. dua orang guru mendapat skor 3 (baik. Pada siklus kedua semua guru tersebut mencantumkan tujuan pembelajaran dalam RKH-nya. Jika dipersentasekan, $100 \%$, terjadi peningkatan $25 \%$ dari siklus I.

Komponen Materi Ajar. Pada siklus pertama semua guru (dua orang) mencantumkan materi ajar dalam RKH-nya (melengkapi RKH-nya dengan materi ajar). Jika dipersentasekan, $75 \%$. dua orang mendapat skor 3 (baik). Pada siklus kedua semua guru tersebut mencantumkan materi ajar dalam RKH-nya. Keduanya orang mendapat skor 4 (sangat baik). Jika dipersentasekan, 100\%, terjadi peningkatan $25 \%$ dari siklus I.

Komponen Alokasi Waktu. Pada siklus pertama semua guru (dua orang) mencantumkan alokasi waktu dalam RKH-nya (melengkapi RKH-nya dengan alokasi waktu). Semuanya mendapat skor 3 (baik). Jika dipersentasekan, 75\%. Pada siklus kedua semua guru tersebut mencantumkan alokasi waktu dalam RKH-nya. Dua orang mendapat skor 4 (sangat baik). Jika dipersentasekan, 100\%, terjadi peningkatan 25\% dari siklus I. 
Komponen Metode Pembelajaran. Pada siklus pertama semua guru (dua orang) mencantumkan metode pembelajaran dalam RKH-nya (melengkapi RKH-nya dengan metode pembelajaran). Jika dipersentasekan, $75 \%$. dua orang mendapat skor 3 (baik). Pada siklus kedua guru tersebut mencantumkan metode pembelajaran dalam RKH-nya. Semua orang mendapat skor 4 (sangat baik). Jika dipersentasekan, 100\%, terjadi peningkatan 25\% dari siklus I.

Komponen Langkah-Langkah Kegiatan Pembelajaran. Pada siklus pertama semua guru (dua orang) mencantumkan langkah-langkah kegiatan pembelajaran dalam RKH-nya (melengkapi RKH-nya dengan langkah-langkah kegiatan pembelajaran). Jika dipersentasekan, 75\%. Kedua guru tersebut orang mendapat skor 3 (baik). Pada siklus kedua, semua guru tersebut mencantumkan langkah-langkah kegiatan pembelajaran dalam RKH-nya. Sehingga kedua guru tersebut mendapat skor 3 (baik). Jika dipersentasekan, $100 \%$, terjadi peningkatan $25 \%$ dari siklus I.

Komponen Sumber Belajar. Pada siklus pertama semua guru mencantumkan sumber belajar dalam RKH-nya (melengkapi RKH-nya dengan sumber belajar). Jika dipersentasekan, 100\%. Baik pada siklus I maupun siklus II

Komponen Penilaian Hasil Belajar. Pada siklus pertama semua guru mencantumkan penilaian hasil belajar dalam RKH-nya meskipun sub-sub komponennya (teknik, bentuk instrumen), dan pedoman penskoran. Jika dipersentasekan, $62,50 \%$. satu orang mendapat skor 2 (cukup baik), dan satu orang mendapat skor 3 (baik). Pada siklus kedua semua guru tersebut mencantumkan penilaian hasil belajar dalam RKH-nya meskipun ada guru yang masih keliru dalam menentukan teknik dan bentuk penilaiannya. Satu orang mendapat skor 3 (baik) dan satu orang mendapat skor 4 (sangat baik). Jika dipersentasekan, 87,50\%, terjadi peningkatan $12,50 \%$ dari siklus I.

Berdasarkan pembahasan di atas terjadi peningkatan yang signifigan pada kompetensi guru dalam menyusun $\mathrm{RKH}$. Oleh karen itu dari penelitian diatas dapat disimpulkan perlunya adanya pembinaan kepada guru dalam penyusunan $\mathrm{RKH}$, RKM dan perangkat administrasi pembelajaran lainnya. Sehingga dengan adanya pembinaan tersebut guru-guru semakin lebih kompeten dalam menyusun administrasi pembelajarannya.

\section{Simpulan dan Saran}

Berdasarkan hasil Penelitian Tindakan Sekolah (PTS) dapat disimpulkan bahwa bmbingan berkelanjutan dapat meningkatkan motivasi guru dalam menyusun RKH dengan lengkap. Guru menunjukkan keseriusan dalam memahami dan menyusun RKH apalagi setelah mendapatkan bimbingan pengembangan/penyusunan RKH dari peneliti. Informasi ini peneliti peroleh dari hasil pengamatan pada saat mengadakan wawancara dan bimbingan pengembangan/penyusunan RKH kepada para guru. Selain itu bimbingan berkelanjutan dapat meningkatkan kompetensi guru dalam menyusun $\mathrm{RKH}$. Hal itu dapat dibuktikan dari hasil observasi /pengamatan yang memperlihatkan bahwa terjadi peningkatan kompetensi guru dalam menyusun RKH dari siklus ke siklus .

Telah terbukti bahwa dengan bimbingan berkelanjutan dapat meningkatkan motivasi dan kompetensi guru dalam menyusun $\mathrm{RKH}$. Oleh karena itu, peneliti menyampaikan beberapa saran. Yang pertama adalah motivasi yang sudah tertanam khususnya dalam penyusunan $\mathrm{RKH}$ hendaknya terus dipertahankan dan ditingkatkan/ dikembangkan. Kedua, $\mathrm{RKH}$ yang disusun/dibuat hendaknya mengandung komponen-komponen RKH secara lengkap dan baik karena $\mathrm{RKH}$ merupakan acuan/pedoman dalam melaksanakan pembelajaran. Ketiga, dokumen RKH hendaknya dibuat minimal dua rangkap, satu untuk arsip sekolah dan satunya lagi untuk pegangan guru dalam melaksanakan proses pembelajaran. 


\section{Daftar Rujukan}

Achmad, S. Ruky. 2006. "Sistem Manajemen Kenerja", PT. Gramedia Pustaka. Jakarta. Aditama

Avalos, B. (2011). Teacher professional developmentin Teaching and Teacher Education over ten years. Teaching and Teacher Education, 27, 10-20.

Depdikbud. (1994). Manajemen Sekolah Dasar, Pegangan Utama Bagi Pendidik danPengajar (Kepala SD, Calon Guru SD, dan Pejabat Pengelola SD). Jakarta: CV Inti Buku Utama Depdiknas. 2003. UU RI No. 20 Tahun 2003 tentang Sistem Pendidikan Nasional. Jakarta: Depdiknas.

Depdikbud. 2004. Standar Kompetensi Guru Sekolah Dasar. Jakarta: Depdiknas.

Depdikbud. 2005. UU RI No. 14 Tahun 2005 tentang Guru dan Dosen. Jakarta: Depdiknas.

Depdikbud. 2005. Standar Nasional Pendidikan. Jakarta: Depdiknas.

Depdikbud. 2007. Permendiknas RI No. 41 Tahun 2007a tentang Standar Proses. Jakarta: Depdiknas.

Depdikbud. 2008. Alat Penilaian Kemampuan Guru. Jakarta: Depdiknas.

Depdikbud. 2009. Petunjuk Teknis Pembuatan Laporan Penelitian Tindakan Sekolah Sebagai Karya Tulis IImiah Dalam Kegiatan Pengembangan Profesi Pengawas Sekolah. Jakarta.

Danim, S. (2002). Inovasi Pendidikan, dalam Upaya Peningkatan Profesionalisme Tenaga Kependidikan Bandung: Pustaka Setia.

E. Mulyasa. 2005. Menjadi Guru Profesional. Bandung: PT. Remaja Rosda Karya

E. Mulyasa. 2005. Implementasi Kurikulum 2004. Bandung: PT. Remaja Rosda Karya

E. Mulyasa. 2006. Kurikulum Yang di Sempurnakan. Bandung: PT. Remaja Rosda Karya

Kuka Udin, 2017. Upaya Meningkatkan Kompetensi Guru dalam Menyusun Rencana Pelaksanaan Pembelajaran Melalui Bimbingan Berkelanjutan di SMP Negeri 10 Kota Ternate. EDUKASI - Jurnal Pendidikan Vol. 15 No.1 Januari 2017

Markos, S., \& Sridevi, M. S. (2010). Employee Engagement: The Key to Improving Performance. International Journal of Busniness and Management, 5(12). Nawawi, Hadari. 1985. Metode Penelitian Bidang Sosial. Yogyakarta: Gadjah Mada University Press.

Nadeem, \& et.al. (2011). Teacher's Competencies andFactors Affecting the Performance of Female Teachers in Bahawalpur (Southern Punjab) Pakistan. International Journal of Business and Social Science 2 (19), 218.

Nawawi, H. Hadari. 1983. Metode Penelitian Deskriptif. Gajah Mada University Press. Yogyakarta 
Stoops, E. dan Johnson, E.R. 1977. Elementary School Administration. New York: Mc GrawHill Book Company

Sudarsono, Fx. 2001. Aplikasi Tindakan Kelas. Jakarta: DIKTI

Sukarni Ani. 2014. Upaya Meningkatkan Kompetensi Guru Dalam Menyusun Rencana Pelaksanaan Pembelajaran Melalui Bimbingan Berkelanjutan Di Sd Negeri Alun-Alun Kabupaten Subang Tahun 2014. BIORMATIKA Jurnal IImiah FKIP Universitas Subang Vol. 3 No 2 September 2017

Sutomo. 2017. Upaya Meningkatkan Kompetensi Guru dalam Menyusun Rencana Pelaksanaan Pembelajaran Melalui Bimbingan Berkelanjutan di UPT SDN Petahunan I Kecamatan Gadingrejo Kota Pasuruan Tahun Pelajaran 2015/2016. Al-Murabbi: Jurnal Pendidikan Agama Islam Volume 3, Nomor 1, Desember 2017 